\title{
The language of evaluation in academic writing research in
} Ghana, 2000-2020: A synthesis

\author{
Afful, Joseph Benjamin Archibald $\bowtie$ \\ University of Cape Coast, Ghana (jafful@ucc.edu.gh) \\ Twumasi, Rita Akele \\ University of Cape Coast, Ghana (rakeletwumasi@ucc.edu.gh)
}

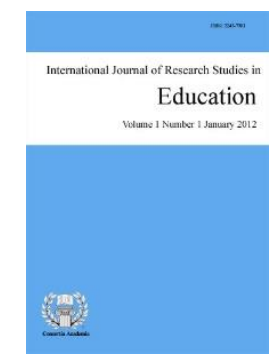

ISSN: $2243-7703$ Online ISSN: 2243-7711

\section{Abstract}

Considerable interest in academic writing, in general, and the language of evaluation, in particular, has been demonstrated in the last two decades among English for Academic and Publishing Purposes (EAPP) researchers, scholars, and practitioners. The paper continues such a trajectory of research by exploring the emerging scholarship on the language of evaluation in academic writing in Ghana, which in the same period has seen an upsurge in the number of tertiary educational institutions and, unsurprisingly, the increasing attention to academic writing. To accomplish the above task, we first provide a conceptual sketch of the key terms underpinning the synthesis. The purposively selected data are then examined through a combination of the qualitative content analysis, exclusion and inclusion, and comparison approaches. The analysis indicates that attention has been paid, in varying ways, to such linguistic/rhetorical and pragmatic resources as reporting verbs, discourse markers, nominalization, the staging of moves/steps, evaluative lexis, critical speech acts, metadiscourse, hedging, and bibliographic citation. A minor finding concerns the dominant use of such research and pedagogic genres as the research article and thesis as the primary data for the synthesis, followed by assessment genres, research proposal and critical review. These findings show that Ghanaian researchers, like many other researchers worldwide, are in touch with the research agenda initiated by EAPP researchers and practitioners in the Anglo-American context. It is hoped that this paper can provide relevant information on the language of evaluation teaching and research in a regional context and motivate similar research efforts in other contexts.

Keywords: academic writing, language of evaluation, Ghana, interpersonality, synthesis 


\section{The language of evaluation in academic writing research in Ghana, 2000-2020: A synthesis}

\section{Introduction}

There is no gainsaying the fact that writing plays a prominent role in the production, dissemination, and evaluation of knowledge in academia. This view is acceptable to scholars and researchers of varying backgrounds such as Academic Literacies, Higher Education, and Theoretical and Applied Linguistics, in general, and English for Academic and Publishing Purposes (EAPP), in particular. A key scholar in Academic Literacies and applied linguist, Hyland $(2005,2009)$ posits that academic writing is about the use of language in academia and how individuals advance their research. In other words, academic writing refers to the ways of thinking, being, and using language in the academic discourse community. Although in this paper, we foreground writing, it is necessary at the onset to recognize, in agreement with Duff (2010), the role of other modes and the influence of technological affordances in the production of genres, registers, graphics, linguistic structures, and interactional patterns — that are privileged, expected, cultivated, conventionalized or ritualized in academia.

Even more interesting for the purpose of the present study is the view that writing is an interaction of persons (for instance, faculty and learners) within a discipline-specific discourse community (Becher \& Trowler, 2001; Bhatia, 1993, 2004; Hyland, 2000; Swales, 1990). Based on the producers of academic writing, Bhatia $(1993,2004)$ identifies two categories, namely professionals and student, where the former is associated with experts and the latter is associated with the apprentice members of the academic discourse community. The experts play gatekeeping roles while the apprentices consisting of $\mathrm{PhD}$, Master, and undergraduate students are considered as "deep participators, ventriloquist, and eavesdroppers" (Pare, Starke-Meyerring \& McAlpine, 2009) respectively. In an academic disciplinary community, writing is also influenced by the beliefs, values, and norms (Bazerman, 1988; Becher \& Trowler, 2001; Hyland, 2000) accepted by its members. Therefore, written academic discourse evinces features that distinguish it from media discourse, legal discourse, religious discourse, among other written discourse types. In fact, Johns (1997) observes that explicitness, intertextuality, objectivity, appropriate genre requirement, metadiscourse, formality, hedging, and disciplinary variation are important features that characterize academic writing. Representations of these characterizing features in written academic genres such as research articles, theses/dissertations, and research proposals/grant proposals (Johns, 1997) are usually evaluated by experts and practitioners, instructors, institutions, and other text mediators (Luo \& Hyland, 2016) or literacy brokers (Lillis \& Curry, 2006).

Given that academic writing is widely acknowledged as interactive and rhetorical (Dontcheva-Navratilova, 2013; Hyland \& Diani, 2009) as a result of the recent "social turn" (or rather "relational turn"), writers report their research findings in order to persuade the readers to accept their claim and, simultaneously, link their work to previous studies, and project themselves as "knowers". It is as much "an act of identity" (Casanave \& Vandrick, 2003; Hyland, 2005, p. 1092) as it is "an act of persuasion" (Pascual \& Unger, 2010) and "transformation of knowledge" (Bereiter \& Scardamalia, 1987; Myers, 1985; Tardy, 2005). Hyland and Diani (2009) share these same views, arguing further that in academic contexts, writers often simultaneously attempt to maintain rapport with readers, argue a position, and signal their allegiance to a particular standpoint or group so that their findings may be accepted. In this sense, academic writing is not only textual but also socio-cognitive and political; not only objective and impersonal but also evaluative and interactive (Adel, 2006; Hyland, 2005; Mauranen, 1993; Thompson \& Hunston, 2000; Vande Kopple, 1985). Hyland (2010, p. 116) continues that academic writing should not be thought of as completely "author evacuated" but rather, as consisting of the language of evaluation, among others. 


\section{Aim of the study and research question}

The present study examines the language of evaluation in academic writing research, whether explicit or implicit, in Ghana, where a great deal of writing in English occurs in its public and private universities and with its unique position as one of the few countries in the world which use English as its sole official language and medium of instruction across all levels of education. Moreover, as Ghana is one of the geographical locations tagged as "off network" in the academic world (Lillis \& Curry, 2006), and where writers are non-native speakers of English, it will be interesting to ascertain the textual practices of its writers in "the intellectual centres" (Flowerdew, 2001, p. 122). Specifically, the present synthesis offers an updating range of relevant studies about the language of evaluation in academic writing produced, first, by Ghanaian (with or without external collaborators) researchers, using data located or provided in Ghana. To this end, the overarching research question is presented as follows:

What issues are discussed by researchers when examining the language of evaluation in academic writing?

The above-mentioned research question is, thus, to examine how the literature characterizes the construction of the overall research activities on various aspects of the language of evaluation in academic writing in an English as a Second Language (ESL) context. In the next section of this synthesis, we review the literature on some key underpinning concepts, followed by a discussion of the methodology adopted. The synthesis and discussion follow. The paper closes with the conclusion and implications.

\section{Conceptual background}

This section considers the concept of "language of evaluation". However, given the slippery and elastic nature of the concept, we also deem it germane to consider pertinent and closely related terms such as "Metadiscourse", "Stance", "Appraisal", "Argumentation", and "Voice", by drawing on points of convergence and divergence. Also, given the considerable influence of the theory of Systemic Functional Linguistics (SFL) in language studies in the last two decades, one of its key strands, the interpersonal mode, is explained. The third key concept worth discussing in this survey is "academic writing".

\subsection{Language of evaluation and related terms}

Thompson and Hunston (2000) proposed the concept of "language of evaluation" which is explained as "the expression of the speaker or writer's attitude or stance towards, viewpoint on, or feelings about the entities or propositions that he or she is talking about. .." (p. 5). Thus, the language of evaluation is concerned with the interpersonal uses of language and how the subjective presence of writers or speakers intrude into communication to convey an attitude to both addressees and the material they discuss. According to Thompson and Hunston, evaluation in texts is crucial in terms of expressing the speaker's or writer's opinion, and maintaining relations (i.e. to manipulate the reader, to persuade him or her to see things in a particular way, or to hedge by adjusting the truthvalue or certainty attributed to a statement). The language of evaluation is, therefore, inherently comparative, subjective, and value-laden. Hyland (2000) sees evaluation as a key feature of academic writing which researchers need so that they can maintain a successful interaction with their readers for research validation in the construction and sharing of knowledge.

As a slippery term, "language of evaluation" encompasses terms such as "stance", "metadiscourse", "voice", "criticality", "argumentation", and "appraisal". These terms are briefly explained, showing how each relates to the concept of "language of evaluation". Specifically, stance concerns the way in which writers present themselves and convey different kinds of opinions, attitudes, credibility assessments, and commitments about propositional content (Hyland, 2008). Thompson and Alba-Juez (2014) offer a revised explanation of "evaluation" and "stance" to show the former as the actual realization of the expression of the speaker's stance or attitude. In this way, stance is thought of as an abstract and umbrella term. Since stance concerns writer's mode of presentation, it also subsumes politeness, argumentation, and criticality. Both experts and learners in the academic discourse 
community are expected to adopt critical posture in respect of the propositional content of their argumentation. In so doing, they are required to pay attention to politeness as a pragmatic strategy in order to strategically handle the "face" of the interactants in a communicative encounter.

Metadiscourse, on the other hand, according to Hunston (2011), is prioritized as the interaction between writer and reader, and evokes a distinction between "primary", or informative discourse, and "secondary", or interactional discourse. Hyland and Tse (2004, p. 157) offer this definition: "Metadiscourse is . . the linguistic resources used to organize a discourse or the writer's stance towards either its content or the reader". Metadiscourse consists of interactive resources and interactional resources. Linguistic features listed under interactive resources include indicators of semantic relations between clauses and text sections and evidentials while those under 'interactional resources' include hedges, boosters, attitude markers, and explicit mentions of either the writer or the reader (Hyland, 2004; Hyland \& Tse, 2004).

In addition, a term close to the language of evaluation is "voice". Often associated with Elbow (1994), a compositionist in the 1980's, voice captures an aspect of the individual, who is not drowned by others but who asserts his or her individuality through language use. Chang (2010) explains that when aligned with stance or evaluation, voice concerns the deployment of evidence and the construction of a convincing argument. Expressed in both written and spoken discourse types (Bakhtin, 1981), voice reveals the intention and perspective of a writer or speaker to the audience. Matsuda (2001) considers voice as a metaphor for capturing, among others, a feature in written discourse that can be perceived by readers, but is not readily recognizable as a single linguistic or rhetorical feature. Seen as self-representation from the Bakhtinian sense of reaccentuating, 'voice' connotes an infinite range of possibilities but from culturally available resources (Ivanic \& Camps, 2001).

Cheung (2017) intimates that since stance is considered to be an individualized assessment from the writer that conveys personal evaluations and commitment (Hyland, 2008), voice subsumes stance in that the voice of a particular social group is articulated as instances of stance as personal voice. The concepts of voice and stance, therefore, encompass the individual, social, and dialogic dimensions, an assertion which is shared by Olivier and Carstens (2018), who distinguish between (1) individualized voice which is stance, echoing Elbow's (1994; 2007) view that voice is a feature that captures the sound of the individual on the page, and (2) socialized voice which is intratextual and intertextual voice since Olivier and Carstens (ibid) see writing as a subject to and the result of social context. For both researchers, voice is mainly associated with Engagement framework, with its dialogical and communicative dimensions (for further reading, see Martin \& White, 2005).

\subsection{Interpersonality in Systemic Functional Linguistics (SFL)}

The language of evaluation with its relatable terms appeals generally to the interpersonal mode of Systemic Functional Linguistics (SFL). SFL operates on three metafunctions: ideational, interpersonal, and textual. Of particular interest to the present discussion is the second metafunction of language which is the Interpersonal.

Halliday (1978, p. 112) explicates that "the interpersonal component represents the speaker's meaning potential as an intruder. It is the participating function of language, language as doing something". This component allows speakers to intrude into the context of situation, both expressing their own attitudes and judgements and seeking to influence the attitudes and behaviour of others. Thus, the interpersonal metafunction expresses the role relationships associated with the situation, including those that are defined by language itself, of questionerrespondent, informer-doubter, among others (Martin \& White, 2005; Matthiessen, 1995). It is a resource for enacting roles and relationships between speaker and listener/reader. Martin and White (2005) posit further that these interpersonal resources are concerned with negotiating social relations: how people are interacting, including the feelings they try to share. The interpersonal metafunction suggests that when people are involved in a communicative event, as in academic writing, they are not only transmitting and sharing meaning; rather, they negotiate, establish, and sustain relationships (Martin \& White, 2005), using language to interact with other people to influence their behaviour, to express their own viewpoint, and to elicit or change theirs. 
Evaluation of entities is also realized through Appraisal which is housed in SFL. Appraisal has been defined as "the semantic resources used to negotiate emotions, judgments and valuations, alongside resources for amplifying and engaging with these evaluations" (Martin, 2000, p. 145). For Martin and Rose (2003), at the heart of the Appraisal Theory is the system of interpersonal meanings whose resources writers and speakers of a language use evaluative resources to negotiate their social relationships, by telling their listeners or readers how they feel about things and people. Appraisal deals with how writers make up identities for themselves in texts, how they present themselves in relation to their readers, and how they construct an audience for their text. Appraisal further analyses the roles and attitudes taken up through interaction between participants in a text.

It is within the interpersonal mode that we see how relationships are established and maintained in the given or demand for information as well as the selection of modals and adverbials to enact relationships. In the academic setting relationships such as editor-in-chief/reviewer and author, student-lecturer/supervisor; Head of Departmentother academic staff; student-administrative staff, supervisor and students, and student-student provide potential means of understanding interpersonality.

\subsection{Academic writing}

In this section, we take a more concrete and specific view of academic writing in orer to complement the earlier one advanced in the introduction to the paper, by drawing on the materiality of the concept of genre as a supportive term (Canagarajah, 2002, 2006). We take the restrictive view that academic writing is an agglomeration of genres mediated through writing by both professionals and novices in the construction, ratification, and dissemination of knowledge (Hyland, 2000, 2009).

From the viewpoint of genre analysts such as the doyen, Swales, and his compatriots such as Bhatia, DudleyEvans, Bazerman, Tardy, Miller, and Hyland, academic writing is designed to serve a specific communicative purpose or a set of communicative purposes: to construct and ratify knowledge; to disseminate knowledge, and to evaluate knowledge. To fulfil these multiple purposes, written communication assumes a specific schematic structure or macro structure to address the issues of content, form, and style (Bhatia, 1993). Written academic genres, thus, represent definable communicative acts with an overarching purpose, which is realizable in subrhetorical acts, known as 'moves'. Moves are further divided into "steps" or "stages" or "sub-moves", which assist in the attainment of this overarching goal. As a rhetorical artefact (Martin, 1992; Tardy, 2009), a written genre is easily identifiable by the frequency of moves, which are noted as core, obligatory, optional, and ambiguous, depending on the classificatory system of moves used (Hyland, 2003, 2004; Huttner, 2010; Santos, 1995), textual space, and sequencing of moves. The second major identifying feature of an academic written genre is its lexicogrammatical choices that are peculiar to each "move".

Like other features of communication, written academic genres do not exist in isolation but form intertextual networks or systems (Bazerman, 1994), linked to each other both diachronically and synchronically. Swales (2004) emphasizes the shift from a static entity towards a dynamic entity by introducing the concept of 'genre networks' and observes that genres are frequently transformed into other genres, associating genres with the metaphor of a network (Swales, 2004). At this point, it is worth drawing attention to Swales' $(1990,1996)$ taxonomy of written academic genres employed within universities and research institutions for scientific and pedagogic purposes, which is presented below in Figure 1:

As can be seen from Figure 1, the primary or research-process genres are directly concerned with research and generally meant for peers whereas those that serve a didactic function are considered as secondary genres. The third category of texts is produced for private or semi-private use, often defined as "occluded"; that is, not open to public scrutiny. In spite of the apparent overlaps, we uphold the classification here as it is essential to the exchange of material, advice, and information between researchers, text mediators, publishers, and university administrators (Lillis \& Curry, 2006; Swales, 1990, 2004). 
Afful, J. B. A., \& Twumasi, R. A.

\begin{tabular}{lll}
\hline \hline Primary genres & Secondary genres & Occluded genres \\
\hline Research article & Textbook & Grant proposal \\
Journal abstract & Course outline & Recommendation letter \\
Conference abstract & Handbook & Request letter for material/advice \\
Thesis/dissertation & Examination essays & Application letter \\
Book & & Submission letter \\
Monograph & & Cover letter \\
Book chapter & & Research proposal \\
Review article & Evaluation letter for promotion \\
Term paper & & Prima facie on promotion documents \\
Edited collection & Editorial correspondence \\
& & Proposal review \\
& & Review report \\
\hline
\end{tabular}

Figure 1. Written academic genre system (Adapted from Swales, 1990, 1996)

\section{Methods}

\subsection{Corpus}

Since the study aimed at evaluating research themes being practiced in the area of EAPP, the corpus consisted of a collection of thirty-nine (39) published and unpublished texts investigating EAPP issues between 2003 and 2020. The period for both data sets is to ensure currency since we are interested in providing updated literature. Published texts include mainly research articles (RAs), edited collections or book chapters, and festschrifts whereas unpublished ones include dissertations/theses. The RAs are selected from appropriate journals in the Humanities, in general, and those in Applied Linguistics, in particular. The book chapters were specifically written for EAPP teachers and students. The dissertations and theses were mainly written by both undergraduate and postgraduate students, with the latter displayed in the Thesis Repositories of some public universities in Ghana.

\subsection{Data collection procedure}

A comprehensive search was conducted to locate the studies exploring the issues and research themes of EAPP, using different electronic databases such as Science Direct, Sage Publication, and ERIC and Commons journals. Second, more than 125 research articles in journals in Applied Linguistics since 2000 were reviewed for issues published. Third, the references cited in the articles found as relevant were reviewed for locating other publications containing data for EAPP themes of research. Fourth, the titles of relevant papers were copied in Google Scholar search engine to find links for these publications via "cited in" applicability. Finally, we emailed those researchers who had published articles in this theme but whose papers could not be readily obtained to send their papers and relevant articles.

A thorough review of texts revealed that many of the 125 studies had not included the language of evaluation, whether implicit or explicit. Moreover, there were some studies which overlapped each other. One of such overlapping studies was included in the list. In cases of doubt, the researchers discussed issues to reach consensus. Several papers and dissertations of some tertiary institutions had paid attention to the error analysis of some written texts, especially by students. Although it can be argued that such studies adopt a prescriptive and, therefore, an evaluative posturing, they were excluded, as they did not focus on "the language of evaluation". Next, the papers were grouped into three categories for convenience, as found in Table 1. Through meticulous evaluation of each category, we decided to exclude the conference papers and some of the RAs because of their lack of 'research qualities' such as those that had employed an autoethnographic approach (e.g. Afful, 2008, 2009). The final distribution of texts that qualified to be included in this study are presented in Table 1. 
The language of evaluation in academic writing research in Ghana, 2000-2020: A synthesis

Table 1

Distribution of text types of data collected

\begin{tabular}{llll}
\hline No & Text type & Frequency & Percentage \\
\hline 1 & Research article & 25 & 64 \\
2 & Dissertation/Thesis & 13 & 33 \\
3 & Book chapter & 1 & 3 \\
& & 39 & 100 \\
\hline
\end{tabular}

As can be seen in Table 1, the research articles dominated in the data set, in terms of frequency of occurrence, followed by dissertations/theses. This shows that experts in Ghanaian universities show more interest in matters related to language of evaluation than learners do. Closely related are genres that receive attention in the thirtynine empirical studies. The distribution of genres as data sets are summarised below:

Table 2

Distribution of genres studied

\begin{tabular}{llll}
\hline No & Genres & Frequency & Percentage \\
\hline 1 & Thesis/dissertation & 21 & 54 \\
2 & Research article & 7 & 18 \\
3 & Assessor's reports & 3 & 8 \\
4 & Examination essay & 2 & 5 \\
5 & Others & 6 & 15 \\
& Total & 39 & 100 \\
\hline
\end{tabular}

As can be seen in Table 2, the dominant genre studied is the thesis, which is a learner's genre. The research article followed in terms of frequency, and then assessors' reports and examination essays. Genres that appear once include bio data, conference paper, personal statement, examination rubric, instructor comment, critical review, abstract, and research proposal. This research situation indicates these genres are yet to garner interest among researchers and scholars of EAPP in Ghana.

\subsection{Data analysis procedure}

After collecting the data, we spent much time to analyse the data. The analysis was generally situated within the qualitative research paradigm, supported by some quantitative means. Specifically, we employed thematic analysis, followed by the explicit coding procedure explained by Glaser and Strauss (1967), the constant comparative method given by Lincoln and Guba (1985), and the inclusion/exclusion criteria (Petticrew \& Roberts, 2006).

Thematic analysis is a commonly adopted, yet infrequently attributed, method for encoding qualitative data (Boyatzis, 1998; Braun \& Clarke, 2006). In employing the method, we searched for "themes" by carefully "reading and re-reading" the data (Rice \& Ezzy, 1999, p. 258). Themes accumulated as data are coded to conform to identifying patterns with similar meaning. The resulting analysis captures rich details through which an interpretation of the underlying data is possible (Yardley \& Marks, 2004). The starting point for identifying the research themes of language of evaluation in the EAPP research was coding the reported and examined variables in each article. As researchers, we read publications from 2000 till 2020 for the titles and abstracts to be able to define the topic areas. The constant comparative method by Lincoln and Guba (1985) stated that the reviewed articles and obtained themes should be constantly compared to reach the final major theme. For example, the researchers read an article, extracted its main theme, and wrote out the theme to form a tentative research theme category. The next publication types were read and their main themes were written and compared to the previous ones. If the themes were similar, the category did not change and the review proceeded to the next papers. If the themes were different, a new category was created. Through this grounded approach, all the selected papers, books, book chapters, and dissertations/theses were reviewed and compared to each other. 


\section{Findings and Discussion}

In this section, we report how the selected studies have explored linguistic, rhetorical, and pragmatic resources in academic writing research in Ghana to show that language use is not neutral and impersonal but personal, interactive, value-laden and evaluative. We first commence with the linguistic resources.

\subsection{Linguistic resources}

A combined team of experts, researchers, and learners, Baidoo (2014), Adika (2015), Gborsong, Awiah, and Appartaim (2018), Afful (2020), and Twumasi (2020) pay attention to some linguistic/discourse features in assessment genres, instructor comments in examination essays, and thesis assessment reports. Baidoo (2014) studies instructor comments in English essays written by third year undergraduate students of the University of Cape Coast. Unsurprisingly, the study captured both negative and positive comments through evaluative lexis such as adjectives, nouns, and verbs. Adika (2015) examined the literature review of postgraduate students and thirtyfive (35) assessors' reports of graduate theses submitted to the University of Ghana, School of Graduate Studies, comprising nine from the Sciences and twenty-six from the Humanities. A key finding in Adika's (2015) study was that in thesis comments on the literature review section cast doubts on candidate's credibility. Moreover, the students' accountability profile was considerably discredited since their communicative style was neither reflective, analytical nor dialectic enough, resulting in less use of evaluative words in the data. Analysis of the second set of data, postgraduate theses, showed that in terms of evaluative language used, students used Research Acts reporting verbs (e.g. "classify", "examine", and "develop"), but the Discourse Acts (e.g. "mention", "explain", and "intimate") were missing in the data. In the case of Afful, the research purpose was to gain insights into their form and content in thirty-four (34) written assessment reports of 19 Master's theses from the Department of English in the University of Cape Coast. A qualitative content analysis, supplemented with descriptive statistics, was adopted. In terms of the evaluative resources used in the examiner comments, both ideational and interpersonal positionings (Ivanic \& Camps, 2001) were adopted. In respect of the former (that is, the content of the thesis reports), overwhelming emphasis in terms of textual space was given to "literature review", followed by "analysis and reporting" and "statement of the problem". Substantial comments were also made on presentational issues. The contribution of the thesis was surprisingly mentioned sparingly. Even more pertinent to the present survey was the fact that the examiner comments included evaluative lexis (e.g. "useful" and "interesting"), adjectival (e.g. "important" and "significant"), and verbal forms (e.g. "confirms"). The most recent large-scale study, Twumasi (2020), drawing on the assumption of evaluation as consisting of a triad (the evaluator, evaluation, and evaluate) makes far reaching and insightful comments on the comments across the various evaluative criteria identified by the UCC School of Graduate Studies. In addition to the negative and positive evaluative comments on the MPhil theses realized through epistemic adjectives, nouns, verbs, and adverbs, mitigating devices featured prominently as a way of demonstrating that the thesis was not only a work in progress but both a pedagogical and research document (Kumar \& Stracke, 2011).

Aligned to the previous pedagogic texts, Gborsong, Awiah, and Appartaim (2018), investigate the nature and location of teachers' written feedback comments on sixty-two (62) students' project essays selected from four Colleges of Education in Ghana, to, specifically, ascertain the syntactic/linguistic form of comments written by the teachers. Gborsong et al. (ibid) identified that hedges which occurred in the evaluations of content were made by using suggestion/request comments, supporting the finding that teachers avoid being overly directive and critical in their comments (Ferris et al., 1997). They also found that the frequent linguistic form was the statement $(116,34.5 \%)$, which is exemplified in giving information comments and asking for information. The imperative syntactic form $(115,34.2 \%)$ was second in frequency. Teachers' critical comments, mostly found in the margins and end points of the projects, were also mitigated.

As potential areas of exploiting the language of evaluation, reporting verbs and discourse markers have attracted the attention of Adika (2003), Yeboah (2014), and Agbaglo (2017b). Specifically, Adika (2003) used the theme structure framework to point to the weak thematic progression that leads to flat paragraphs and undeveloped 
rhemes in university students' writing. Agbaglo investigated the use of reporting verbs in RAs written by lecturers in the Department of English, UCC, using Hyland's (2002) classification of reporting verbs as the theoretical framework. The study, evoking the findings of Adika (2015), found that discourse acts type of reporting verbs (e.g. "states", "explains" and "indicates" was preferred by lecturers, as compared to the research acts category of reporting verbs ("examine", "classify" and "develop"), and the cognitive acts category of reporting verbs ("consider", "think" and "believe"). Agbaglo's (2017b) finding on the use of more discourse acts verbs is similar to the findings of Twumasi (2012) who focused on graduate writings, and not expert writings. Twumasi (2012) investigated citation practices of graduate students' theses at a Ghanaian university. As one of its research questions, the study focused on the kinds of reporting verbs used at the Literature Review section of MPhil theses in the disciplines of English and Curriculum Studies, University of Cape Coast. The analysis of the study showed that Curriculum Studies students used discourse act verbs ("mention", "assert", and "intimate") more whilst Research Acts ("observe", "analyse" and "see") and Cognitive Acts ("view", "believe" and "think") were preferred by their English counterpart. The discourse act verbs involved verbal expressions which were appropriate in qualitative argumentation schema, allowing for explicit interpretation and signalling reluctance of writers to commit themselves to a distinctive position towards the viewpoints of others. Cognitive and research act verbs, on the other hand, stressed the role of reasoning in argumentation and the construction of knowledge. Yeboah (2014) examined the discourse markers employed by undergraduate students in writing their Literature Review. Her findings indicated that all the five discourse markers identified by Martinez (2004), following Frazer's (1999) taxonomy, were present. However, the elaborative discourse markers were frequently used by the undergraduate students.

A cross-disciplinary (Sociology, Economics, and Law) study in nature, Ngula (2017) examined epistemic modal verbs in RAs, using corpus linguistics methods to ascertain national (Ghanaian) and international (nonGhanaian) usage in terms of depth, diversity, phraseological patterns and degrees of epistemic strength. The study showed that international scholars used more epistemic modal verbs than their Ghanaian counterparts, suggesting that Ghanaian authors were more direct and overly categorical in the ways that they presented their research claims. Again, the modal verb may as a mitigating device for research claims was the most common epistemic resource. Also, Ghanaian writers used will more than would to portray politeness. Next, international writers preferred might, to could, in order to express epistemic claims; Ghanaian writers, on the other hand, used could more than might for this purpose. Last, strong epistemic claims (boosters) like the modal verbs will and must showed a high level of confidence in the truth of the proposition expressed by these writers, but weak epistemic claims (hedges) used the modal forms may, could, and might to significantly reduce the level of commitment to the proposition.

Focusing on the Results and Discussion section of 20 MPhil theses in Health Sciences and English, and on an aspect of evaluative verbs, Abdullah (2016) examined types of tense. The study employed mixed method approach, and found that the simple present and simple past tense occurred most frequently in the results and discussion section of the MPhil theses in both disciplines. More relevant to the present study was the fact that commentary and evaluation, signalling, and references to previous research were observed as some functions of the tense forms identified in the study. In addition, the study observed that author's point of view affected the choice of tense form. Another point of divergence in these studies is that Agbaglo (2017b) and Ngula (2017) focused on RAs while Abdullah (2016), Musa (2014), and Twumasi (2012) focused on the thesis, a graduate writer genre, with attention on such part-genres as Introduction, Literature Review, and Results and Discussion.

The terrain of the evaluative language research takes a different turn when Agbaglo (2020) explores the use of process nominalisation as grammatical metaphor in 120 research article abstracts in Applied Linguistics, Economics, and Biology. The study revealed that process nominalisations are used, ideationally, to create taxonomy; interpersonally, to appraise; and, textually, to achieve cohesion. In line with Martin (2000), who notes that nominalisations serve as resource for both positive and negative evaluation, it is not surprising that Agbaglo observes some element of stance construction inherent in both verbal and mental process of nominalisations. As stance nominalisations (Jiang \& Hyland, 2015), when used strategically, nominalisations of both verbal and mental processes allow writers to negatively and positively evaluate the views of other researchers and burnish their own 
views (Hao \& Humphrey, 2012). Sarfu-Adu's (2015) study of 50 research article abstracts, similar to the genre considered by Agbaglo (2020), indicates that the Science, rather than the Humanities, data demonstrate the incidence of more nominalisations as grammatical metaphor; thus, leading him to conclude, "As a consequence of using nominalization, writing becomes more abstract, formal and elevated". (p. 65). Although the 'that-noun clause' has an evaluative potential and features in interaction and metadiscourse research, this is unfortunately muted in Favour's (2014) work on the use of nominal clause in 60 examination essays of Level 300 students from English and Agriculture disciplines apparently because of their background as learners.

Apart from the studies considered above (e.g. Agbaglo, 2017b, 2020; Sarfu-Adu, 2015; Twumasi, 2012) that investigated evaluation from a pragma-linguistic viewpoint, concentrating on politeness, hedging, and reporting verbs, Afful (2017a) seems to have been the only that employed Appraisal Theory, specifically, using the Engagement strand. Afful employed a cross-disciplinary approach to examine the literature review section of 45 theses across three disciplines in University of Ghana: Linguistics, Geography, and Nutrition and Food Sciences. The study aimed to identify how MPhil students used engagement resources to show commitment to propositions made, and to dialogically contract or expand the discursive space in LR. The study showed that postgraduate students in the Sciences used more contractive engagement resources (e.g. "indicate", "show", and "demonstrate") than their mates in the other two disciplines. Again, the study revealed that the Sciences (Nutrition and Food Sciences) theses used more expansive resources (e.g. "may", "perhaps", and "probably") than those in the Social Sciences (as seen in Geography) theses and Humanities (as seen in Linguistics) theses.

\subsection{Rhetorical resources}

As an emerging area in language of evaluation research in Ghana, metadiscourse has received attention by Akoto $(2013,2018,2020)$. Two of his studies are included in this survey. Adopting Hyland's (2005) interpersonal metadiscourse theory as both the theoretical and analytical frameworks, Akoto (2013) investigated metadiscourse use in the Introduction and Literature Review sections of the theses selected from English language and Sociology masters' thesis in a Ghanaian university. The analysis revealed that hedges, engagement markers, and self-mention were preferably used in the Introduction while the Literature Review recorded more of evidentials, boosters, and attitude markers in both English and Sociology theses. However, English theses writers used more code glosses, evidentials, endophorics, frame markers, engagement markers, and self-mentions than theses selected from Sociology. Akoto's (2018) study turns attention to the use of metadiscoursal devices in the Introduction Chapters in 20 English Language and Sociology Master's theses, drawing on the modified version of Hyland's Metadiscourse model. A key finding of the study was that hedges ranked first across both disciplines, and except booster and attitude markers which interchanged positions in the two disciplines. Thus, from the two studies (Akoto, 2013, 2018), it can be seen that the findings on the use of hedges and other engagement markers appeal to the interpersonal node of SFL, showing how evaluation helps in maintaining interpersonal relationship with readers (here, metadiscourse).

An exclusive study on hedging, Musa's (2014) data consisted of English and Chemistry Masters' theses in the University of Cape Coast. Employing a mixed method approach, the study revealed that hedging in English and Chemistry Masters' theses performed three pragmatic functions: made claims accompanied by some degree of uncertainty; prevented any future criticism capable of damaging image, and gained reader acceptability by presenting facts as tentative. Researchers in Chemistry seemed to have a deeper concern for the level of certainty or uncertainty regarding their propositions; thereby, showing how reliable their claims could be. Like Musa (2014), Edusie (2015) investigated hedging strategies among Advanced L2 users of English. Her study was devoted to academic writing in Ghana in three universities - Kwame Nkrumah University of Science and Technology, University of Education, Winneba, and University of Cape Coast. She analysed MA theses from these selected institutions and supplemented the data with ICE-Gh Academic Writing, differing from Musa (2014) who relied solely on one data set. Some findings of the study included the epistemic/non-epistemic use of hedging devices, with many pragmatic functions and complexity levels. Again, the study showed that differences existed in the use of hedging devices, depending on the level of proficiency of the Advanced L2 users of English. Epistemic nouns

112 Consortia Academia Publishing (A partner of Network of Professional Researchers and Educators) 
The language of evaluation in academic writing research in Ghana, 2000-2020: A synthesis

were least used in the study. Modals (may, might), adjectives (possible, probable), adverbs (usually, probably), evidential verbs (seem, appear), judgement verbs (suggest, think) and nouns (likelihood) were also found in the analysis of the data; thus, revealing different nuances to evaluation.

Rhetorical verbs receive attention in the data set for the present survey. Often found in examination rubrics, rhetorical verbs (also described as "directive verbs") are carefully selected to indicate what thought processes and actions student must exhibit to provide evidence that learning has occurred. In this survey, following earlier studies such as Henderson (1982), Horowitz (1986a, 1986b, 1989), and Lewis and Starks (1997), we consider Ansong (2011) that demonstrates the evaluative potential of rhetorical verbs in examination questions of the departments of English and History in the University of Cape Coast. Ansong's textual analysis of four main rhetorical verbs such as "discuss", "explain", "examine", and "comment" out of eleven and nine different tokens of rhetorical verbs from English and History respectively showed distinct meanings that bothered on a stance to be adopted.

An emerging area in EAPP research in Ghana, genre studies have assumed two dimensions while addressing directly or implicitly the issue of language of evaluation: a) the staging of moves in introductions (e.g. Adika, 2014; Ankomah \& Afful, 2019; Coker \& Coker, 2012; Daniels, 2017; Davies, 2014), conclusion (Adzimah, 2019), and b) the move analysis of specific genres such as titles, acknowledgements, and other part-genres. First, Adika (2014) takes a genre approach (CARS model) to analyse 59 introductions of RAs published in Legon Journal of the Humanities, from 2005 to 2010. Specifically, he examines the space that the contributors to the journal allot to themselves through the linguistic devices used in signalling gap statements, along with the extensiveness of references to previous work as a way of situating and mainstreaming their research. The findings revealed that the authors of these RAs did not exploit Step 3 (reviewing items of previous research) under Move 1 in order to reinforce the research niche being claimed in Move 2. Thus, it can be said that the evaluative language which would have accompanied this review was missing since that step (Step 3) was missing, too, in the analysis of the data.

Similarly, Daniels (2017) adopted the genre approach in examining forty MPhil research proposals written by graduate students of English Language Studies and Agricultural Science in a public Ghanaian university. Combining the genre approach and Halliday's SFL, the study revealed that, among other findings, the students of the proposals studied employed stance in Move 1, establishing a territory, when reviewing items of previews studies, indicating the research author's position on the findings or claims. The authors made counter-claims, indicated the gap, and allowed themselves to continue in traditions (which were all realized in Move 2, establishing a niche). It is interesting to observe how the learners manage to stage successfully the rhetorical moves, whereas Adika's (2014) study alludes to experts who 'struggle' to do these. Although Afful (2005) took a cross-disciplinary approach like Daniels (2017), he focused on the introduction and conclusion of 180 examination essays (60, each from the departments of English, Sociology, and Zoology at the University of Cape Coast) written by second-year undergraduates. Focusing on the introduction for lack of space, of relevance to the present studies is the finding that, in terms of linguistic features, English examinees differed from their Sociology and Zoology counterparts in their deployment of verbal processes, metatextual expressions, and personal pronouns to instantiate Move 3 (previewing). Previewing inherently expresses attitudes towards previous studies or researchers. Sociology examinees differed from their English and Zoology counterparts in the use of attribution in Move 2 (engaging closely with the issue). English and Sociology scripts differed from each other in the use of evaluative terms in Move 1, modalized processes, which were used to express epistemic stance towards propositions in Move 2, and personal pronouns to show writer/author visibility in Moves 1 and 2. Devoting attention to the introductions of 120 examination essays, Afful (2012) examined the rhetorical choices made by second-year undergraduates in Literature-in-English and Sociology courses in a Ghanaian public university. In using Swales' rhetorical move approach and Halliday's Systemic Functional Grammar, the study revealed that, first, the Sociology introductions differed from the English introductions in the deployment of definitions in Move 1 (establishing a territory). Second, the English introductions differed from the Sociology ones in the use of verbal processes in Move 2 (engaging closely with the issue) and the use of personal pronouns, discourse verbs, and purpose expressions in Move 3 (previewing). Both Sociology and English introductions further utilized lexical repetition as a principal 
rhetorical feature for emphasis.

Some studies on establishing a niche show that Ghanaian writers prefer 'Indicating a gap" to other rhetorical strategies (Adika, 2014; Coker \& Coker, 2012; Davis, 2014) in the framing of statement of the problem, which has a huge evaluative potential. Ankomah and Afful's (2019) study on establishing a niche utilized two groups of students, undergraduate and postgraduate. This paper investigates the rhetorical strategies employed by Language students in the Department of English, University of Cape Coast, to establish a niche in their introduction sections. Fifty-two introductions were collected from both undergraduate dissertations and postgraduate theses and subjected to a qualitative content analysis. In general, postgraduate students employed four strategies (Indicating a gap, Counter-claiming, Establishing problem and need, and Continuing tradition) while the undergraduates relied on three (Indicating a gap, Establishing problem and need, and Continuing tradition). This means that the difference between the two variables (PG and UG) is Counter-claiming. The most frequently used rhetorical strategy for both PG and UG writers was "Indicating a gap", but the least was "Continuing tradition". "Question raising" was not identified in the data studied. Closely related to the above-mentioned studies is Owusu and AdadeYeboah (2014) who suggest that the reason for the ineffective use of thesis statement in the expository essays of students of two prominent private universities in Kumasi, Ghana (Christian Service and Ghana Baptist University Colleges) is the inappropriate use of negative expressions.

Other studies that do discuss some aspects of the language of evaluation investigate genres such as titles (Afful, 2017b) dissertation/thesis acknowledgement (e. g. Afful \& Awoonor-Aziaku, 2017; Afful \& Mwinlaaru, 2010), list of references (Afful, 2012; Afful \& Janks, 2012), and biographical statement (Afful, 2015; Mwinlaaru). For example, Afful (2017b) explores the title length, syntactic structure, and informativity of conference paper titles in Applied Linguistics, using a data set of 689 conference paper titles and a mixed method approach. Of relevance to the present study, also, are the findings on the use of verbal expressions, one of which is the metaphorical use of verb forms in the titles to create a mental picture of an activity being performed; thereby enhancing the comprehension of conference paper titles (e. g. "Mapping linguistic diversity in Europe"). The use of these verbs which may be referred to as activity verbs rest in the Material Process of Transitivity (SFL). Another front device in most theses, 'Significance of the Study' section attracts the attention of Aboagye (2015), who focuses on the undergraduate students. Unsurprisingly, the work reveals the difficulty undergraduate students face in selecting appropriate evaluative lexical items in contrast to Lim's (2008) which was carried out on the same part-genre though by experienced writers on the use various of rhetorical and linguistic strategies to highlight the significance of their research in the terminal portions of their papers.

Contrary to the title and the 'Significance of the Study' section in the thesis introduction as front rhetorical devices in EAPP is the reference list variously referred to as 'bibliographic citation', 'works cited', and 'references', which is popularly studied as citation analysis and bibliometric studies in Information Science and Librarianship. Whereas in the first study (Afful, 2012), the findings are 'neutrally' presented, in Afful and Janks (2013), a critical discourse analytical perspective is adopted. This approach enables identification of alliances, misalliances, and preferences in terms of the choice of such variables as publication types, chronology, and authoring practices. For instance, doctoral Science students preferred research articles (RAs) whiles the Social Sciences and Humanities students preferred books or monographs. The study of Afful and Janks also showed the preponderant citing of studies with multiple authorship by students in the Sciences, unlike the Social Sciences and Humanities students whose citations were more of sole authorship.

A part-genre that bears mentioning is the acknowledgement section of theses and dissertations. Specifically, Afful and Mwinlaaru (2010) explore the interface between identity construction and the linguistic features of a Master's dissertation acknowledgement, written by a student of Literary Studies, using a two-pronged analytical framework. The paper established that the writer of the acknowledgement systematically varied these linguistic choices at the lexical, grammatical, and discoursal levels in order to construct varying and different identities. The use of complex vocabulary (e.g. “...my monumental gratitude...”) for enacting superior-subordinator relationship was formal. Also noticeable was the use of politeness markers (e.g. "I wish to...") as a hedging device and adjective 
(e.g. "profound" and "insightful") to maintain a distant relationship with the reviewer. Last was the hybridization of the dissertation acknowledgement in terms of the incorporation of formal and informal linguistic elements, thereby highlighting the highly interpersonal nature of the acknowledgement (Hyland, 2003; 2004b).

Still on the same part-genre, thesis acknowledgement, as done by Afful and Mwinlaaru (2010), Afful and Awoonor-Aziaku (2017) examine the naming practices adopted by postgraduate students in a Ghanaian university. In contrast to Afful and Mwinlaaru (2010), Afful and Awoonor-Aziaku (2017) used a data set of 16 acknowledgement texts of Master's theses submitted to two departments (English and French). The analysis of the data revealed that, among others, the choice of these address terms (title plus full name, full name, title plus first name, first name, kinship terms, and honorifics) was influenced by such interpersonal factors as social distance, politeness, and solidarity; showing that the language used in the acknowledgement sections was neither neutral nor impersonal but personal and value-laden. In another cross-disciplinary study, Afful and Mwinlaaru (2012) explored the rhetoric of 20 acknowledgement section of Master's dissertations in three sub-disciplines of Education: Guidance and Counselling, Educational Administration and Management, and Science and Mathematics Education. A key finding was that in the obligatory thanking move where references were made to different individuals, there was variation in the choice of language to establish these different identities and different levels of formality concerning the nature of relationship between the thanker and thankee.

Focusing lastly on undergraduate students, but cross-disciplinary in nature as Afful and Mwinlaaru (2012), Afful (2016) examined 200 dissertation acknowledgements from two departments, English, and Entomology and Wild Life at a Ghanaian university. He employs a mixed method approach to analyse the schematic structure and lexico-grammatical choices in 200 DAs from two departments, English, and Entomology and Wild Life. The dissertation acknowledgements' deployment of gratitude-related terms (e.g. "My heartfelt thanks go to..."), socioculturally conditioned names (e.g. honorific titles like "Dr." and "Prof"), and hybridized linguistic forms (realized in sociolinguistic terms as 'code-mixing'), as established in earlier studies (Afful \& Mwinlaaru, 2010; Afful \& Mwinlaaru, 2012), far from evincing a neutral standpoint, reflect various interpersonal elements - formality, politeness, social distance, and power.

Although recognised as an occluded genre, the personal statement is an important promotional genre in most universities in the USA (Brown, 2004; Ding, 2007; Vossler, 2007), as it is required in the dossier of application of an applicant. Nkansah and Afful's (2017) move analysis of personal statements shows that Ghanaian university students draw on a seven-move pattern: six obligatory moves (Caption, Background, Programme, Choice of School, Credentials, Career Objective) and one optional move (Closure). It is not surprising that the Credential move occupied the greatest textual space as it sought to present academic credentials, non-academic credentials, distinctive personal qualities and relevance of credentials as key issues to be addressed. Some applicants state their distinctive qualities through adjectives highlighted in bold in such expressions as "good interpersonal skills" and "good communicative skills, hardworking", "self-motivated" "determined individuals", "lively", "energetic", "sociable", "efficient and effective", evoking self-glorification strategy (Bhatia, 1993). In separate studies, Afful and Mwinlaaru focus on biographical statements. Afful (2015) specifically examines 25 biographical statements written by both lecturers and students from Department of English and other cognate departments (such as Linguistics, Ghanaian Languages, and French) in some universities in Ghana to accompany research articles meant for a festschrift. In what is included and the ways it is assembled, the bio reveals the negotiation of impression management (here, mediated through seniority). Studying bios adds to our understanding of the construction of identity in academic contexts, and the ways that seniority potentially impacts on this construction in the face of institutional pressures towards conformity.

\subsection{Pragmatic resources}

Agbaglo (2017a) studied politeness strategies in the Analysis and Discussion sections of 20 RAs produced by faculty from Department of English, University of Cape Coast. The study found that lecturers used more negative politeness strategies than positive politeness strategies in their RAs. It was established that lecturers used positive 
politeness strategies (i.e. certainty adjectives, speculative expressions, imperatives and creating rapport) to emphasize solidarity and involvement with colleague researchers, and negative politeness strategies to emphasize the independence of the reader. Negative politeness strategies included modals, hedging, passive voice, impersonal construction and tentative verbs.

Bisilki and Bisilki (2017) investigate evaluative speech acts in critical reviews written by graduate students at University of Cape Coast (UCC). Adopting the content analysis approach, the study revealed that the reviews of the graduate students contained more positive comments (e.g. "The article is very detailed, elaborative and informative.") than negative evaluative speech acts (e.g. "The paragraphs were too long, which made reading slow and very difficult to extract the meaning of what was presented."). Again, the students focused on the text rather than the author reviewed, but the critical comments were mitigated to reduce the full import of the criticism or the negative comments, using modal verbs (e.g. "could", and "might"), Adverbs ("probably", "perhaps", and "maybe"), and contrasting conjunctions (e.g. "although", "even though", and "however").

Thus, the above studies show that evaluation is employed in the Ghanaian context by both experts and novices (postgraduate and undergraduate students) as part of their participation in the construction, ratification, and assessment of various written genres and part-genres. Politeness strategies in identity construction, formality, and naming practices to enact and maintain relationships with addressees were also employed. The use of linguistic, rhetorical, and pragmatic resources provides credible evidence of the interactive, personal and evaluative nature of academic writing in an under-researched area in Kachru's (1992) Outer Circle.

\section{Conclusion}

The paper has explored the emerging scholarship on evaluation in academic writing in Ghana, which in the last two decades has seen the upsurge of tertiary institutions as a result of some new policy directions in the tertiary educational landscape and the attendant increasing attention to academic writing. We provided a conceptual sketch of the key terms and notions. A synthesis of purposively selected 39 studies conducted by a range of researchers, both faculty and students, on the language of evaluation in academic writing in Ghana was undertaken, by way of addressing the key linguistic, pragmatic, and rhetorical features. Content analysis (or thematic analysis), inclusion/exclusion, and comparative approaches were adopted in line with Nartey and Mwinlaaru (2019).

Analysis of the data showed that, as in several studies in Anglo-American setting (e.g. Hunston, 1993; 1994; 2011), the language of academic writing is not neutral and impersonal; instead, it is personal, interactive, valueladen, and evaluative. The study has highlighted the fact that evaluative language exists in various forms of academic writings in Ghanaian tertiary institutions. The linguistic, rhetorical, and pragmatic features that have attracted scholars and researchers of EAPP in Ghana include politeness, modality, tense usage, reporting verbs, evaluative speech acts, evaluative lexis, nominalization, formality, staging of moves, etc. Genres that have attracted attention in evaluative studies in academic writing research in Ghana have seen understandably the rivalry between research articles and theses/dissertation on one hand and part-thesis genres, on the other hand; with sparse attention being paid to other genres such as research proposal, examination essays, written feedback comments, and thesis assessment reports.

More generally, we can state that there is a healthy and developing (but slow) interest in the language of evaluation in academic writing. In restricting our literature search to the most widely available sources (international journal articles, edited book chapters published in English, and theses), we should point out that there may be a lot of work, particularly of a practical nature, going on that we have not reviewed here. Nevertheless, based on what we have included in this review, we can be confident that the interest in the language of evaluation in the academic writing context is gaining some attention. It is moving from being a niche interest of a small number of dedicated researchers such as Afful and Adika and other practitioners towards becoming a more mainstream area of research for ever-increasing numbers of teachers and learners.

Considering the above findings, it will be revealing if further studies can focus on "unpopular" genres such as 
the research proposal, grant proposal, $\mathrm{PhD}$ thesis, critical reviews, annotated bibliography, and term paper alongside part-genres like Discussion, Methodology and Conclusion since these are rhetorical sections that are equally important in the ratification of knowledge in the academic discourse community. Moreover, more corpusbased and ethnographic approaches could be adopted in the study of evaluative language in academic writing alongside other functional approaches like Appraisal and Metadiscourse. Although this synthesis is aimed to give a systematic analysis of the research on academic writing in Ghana, it has still an obvious limitation in terms of its number, given the recent changes in the landscape of tertiary education in Ghana which has led to an increase in the number of colleges of education, technical universities, and public universities. This should be overcome by future research. Similar studies on the language of evaluation in academic writing can be undertaken in other regional contexts.

\section{References}

Abdullah, S. A. (2016). Tense in academic discourse: A study of two disciplines. Unpublished MPhil thesis. University of Cape Coast, Ghana.

Aboagye. (2015). Genre analysis of the significance of the study section of undergraduate dissertations in the Faculty of Arts, University of Cape Coast. Unpublished BA dissertation, University of Cape Coast.

Adel, A. (2006). Metadiscourse in L1 and L2 English. Philadelphia: John Benjamins.

Adika, G. S. K. (2003). A theme-structure approach to evaluating aspects of university students' expository texts. Legon Journal of the Humanities, 14: 55-78.

Adika, G. S. K. (2014). Swales' CARS model and the metaphor of research space: An illustration with an African journal. Legon Journal of the Humanities, 25, 58-75.

Adika, G. S. K. (2015). Credibility and accountability in academic discourse: Increasing the awareness of Ghanaian graduate students. Practice and Theory in Systems of Education, 10(3), 227-244.

Adzimah, E. C. (2019). Genre analysis of undergraduate dissertation conclusions. Unpublished MPhil dissertation, University of Cape Coast.

Afful, I. (2016). Dialogic positioning in literature reviews of MPhil Theses. Unpublished MPhil thesis. University of Cape Coast, Ghana.

Afful, J. B. A. (2005). A rhetorical analysis of examination essays in three disciplines: The case of Ghanaian undergraduate students. Unpublished $\mathrm{PhD}$ thesis. National University of Singapore.

Afful, J. B. A. (2008). Research proposal and thesis writing: Narrative of a recently graduated researcher in Applied Linguistics. Nebula, 5(4), 193-211.

Afful, J. B. A. (2009). Advanced academic literacy and the role of academic editors in research writing. Nebula, 6(4), 19-39.

Afful, J. B. A. (2012). Introductions in examination essays: The case of two undergraduate courses. Across the Disciplines, 1-14.

Afful, J. B. A. (2015). Self-representation in biographical statements in a festschrift at a Ghanaian university Drumspeak, 5(1), 102-138.

Afful, J. B. A. (2016). A genre study of undergraduate dissertation acknowledgements in a Ghanaian university. ESP Today, 4(2), 202-224.

Afful, J. B. A. (2017). A linguistic analysis of conference titles in Applied Linguistics. International Journal of Foreign Language Teaching \& Research, 5(18), 11-25.

Afful, J. B. A. (2020). The discourse of thesis assessment reports in a disciplinary community at the University 
of Cape Coast: An exploratory study. International Journal of Language, Literature and Gender Studies, $9(1), 117-134$.

Afful, J. B. A., \& Awoonor-Aziaku, L. (2017). Naming in master's thesis acknowledgements within two Ghanaian university departments. Africology, 10(9), 252-273.

Afful, J. B. A., \& Janks, H. (2013). The politics of citation: An analysis of doctoral theses across disciplines. Critical Approaches to Discourse Analysis across Disciplines, 6(2), 193-210.

Afful, J. B. A., \& Mwinlaaru, I. N. (2010). The construction of multiple identities in the acknowledgement section of a Masters dissertation. English for Specific Purposes World, 30(9), 1-26.

Afful, J. B. A., \& Mwinlaaru, I. N. (2012). Sub-disciplinary variation and rhetoric in dissertation acknowledgements written by education Students: The case of the university of Cape Coast, Ghana. In D. D. Kuupole \& M. K. Kambou (Eds.), National development through language education (pp. 79-111). Cape Coast, Ghana: University of Cape Coast Press.

Afful, J. B. A., \& Nkansah, N. B. (2018). A move analysis of personal statements written by Ghanaian university students. Language, Discourse \& Society, 6(1), 84-101.

Agbaglo, E. (2017a). The use of politeness strategies in the analysis and discussion sections of English research articles. Research on Humanities and Social Sciences, 7(9), 30-42.

Agbaglo, E. (2017b). The types and the frequencies of reporting verbs in research articles written by lecturers in a Ghanaian university. Journal of Literature, Languages and Linguistics, 34, 51-57.

Agbaglo, E. (2020). Grammatical metaphor in academic writing: Functional diversity of process nominalization in research article abstracts across disciplines. Unpublished MPhil thesis, University of Cape Coast.

Akoto, O. Y. (2013). Metadiscourse use in English Language and Sociology Masters' Theses in a Ghanaian university. Unpublished MPhil thesis. University of Cape Coast, Ghana.

Akoto, O. Y. (2018). Same chapter, different disciplines: Metadiscourse use in introductions of English language and Sociology Masters' theses. Journal of the IATEFL ESP SIG, 51, 17-27.

Akoto, O.Y. (2020). Metadiscourse within a discipline: A study of introduction and literature review chapters of sociology masters' theses. Indonesian Journal of Applied Linguistics 10 (2), 471-480.

Ankomah, C., \& Afful, J.B.A. (2019). Establishing a niche in research: Rhetorical strategies in undergraduate and postgraduate writings in the Department of English, University of Cape Coast. The Journal of Teaching English for Specific and Academic Purposes, 7(3), 359-374.

Ansong, J. (2011). A comparative study of rhetorical verbs in examination questions: The case of English and History departments of the University of Cape Coast. Unpublished BA dissertation, University of Cape Coast.

Baidoo, N. D. (2014). Discourse analysis of instructor comments in English essays: The case of third year undergraduate students of the University of Cape Coast. Unpublished BA dissertation, University of Cape Coast.

Bakhtin, M. M. (1981). The dialogic imagination: Four essays. In M. Holquist (Ed.), C. Emerson \& M. Holquist (Trans.). Austin, TX: University of Texas Press.

Bazerman, C. (1988). Shaping written knowledge. Madison, WI: University of Wisconsin Press.

Bazerman, C. (1994). Constructing experience. Carbondale: Southern Illinois University Press. 
The language of evaluation in academic writing research in Ghana, 2000-2020: A synthesis

Becher, T., \& Trowler, (2001). Academic tribes and territories: Intellectual enquiry and the cultures of disciplines. Buckingham, UK: Open University Press.

Bereiter, C. \& Scardamalia, M. (1987). The psychology of written composition. Hillsdale, NJ: Lawrence Erlbaum.

Bhatia, V. (1993). Analysing genre: language use in professional settings. London: Longman.

Bhatia, V. (2004). Worlds of written discourse: A genre-based view. London: Continuum.

Bisilki, A. K., \& Bisilki, I. (2017). Evaluative speech acts of Ghanaian graduate students: A case study of University of Cape Coast, Ghana. Contemporary Journal of African Studies, 5(1), 89-114.

Boyatzis, R. E. (1998). Transforming qualitative information: Thematic analysis and code development. Thousand Oaks, CA: Sage.

Braun, V., \& Clarke, V. (2006). Using thematic analysis in psychology. Qualitative Research in Psychology, 3(2), $77-101$.

Brown, R. M. (2004). Self-composed: Rhetoric in psychology personal statements. Written Communication, 21(3), 242-260.

Canagarajah, S. A. (2002). A geopolitics of academic writing. Pittsburgh: University of Pittsburgh Press.

Canagarajah, S. (Ed.) (2006). Reclaiming the local in language policy and practice. Mahwah, NJ: Lawrence Erlbaum.

Casanave, C. P., \& Vandrick, S. (2003). Writing for scholarly publication: Behind the scenes in language education. Mahwah, NJ: Lawrence Erlbaum.

Chang, P. (2010). Taking an effective authorial stance in academic writing: Inductive learning for second language writers using a stance corpus. Unpublished $\mathrm{PhD}$ thesis The University of Michigan.

Cheung, E. (2017). Development of evaluative stance and voice in postgraduate academic writing. Unpublished PhD thesis. The Hong Kong Polytechnic University \& University of Technology Sydney.

Coker, W., \& Coker, W. (2012). Stating the research problem: A genre-based study of English language MPhil theses in a Ghanaian university. Language in India, 12, 509-518.

Daniels, J. B. (2017). Generic moves in selected MPhil research proposals from a public university in Ghana. Unpublished PhD Thesis. University of Ghana, Ghana.

Davis, W. C. (2014). A genre analysis of the statement of the problem section of masters'theses in two faculties in the University of Cape Coast. Unpublished MPhil thesis in the Department of English, University of Cape Coast.

Ding, H. (2007). Genre analysis of personal statements: Analysis of moves in application essays to medical and dental schools. English for Specific Purposes, 26, 368-392.

Dontcheva-Navratilova, O. (2013) Authorial presence in academic discourse: Functions of author-reference pronouns. Linguistica Pragensia, 23(1), 9-30.

Duff, P. (2010) Language socialization into academic discourse communities. Annual Review of Applied Linguistics, 30, 169-192.

Edusie, J. S. (2015). Academic writing in Ghana: Hedging among advanced L2 users of English. Unpublished MPhil thesis. Kwame Nkrumah University of Science and Technology, Ghana.

Elbow, P. (Ed.). (1994). Landmark essays on voice and writing. Davis, CA: Hermagoras. 
Afful, J. B. A., \& Twumasi, R. A.

Elbow, P. (2007). Voice in writing again: Embracing contraries. College English. 7. Retrieved from https://scholarworks.umass.edu/eng_faculty_pubs/7

Favour, N. E. (2014). The use of nominal clause in students'writing: An analysis of selected scripts in the Department of English and School of Agriculture. Unpublished BA dissertation, University of Cape Coast.

Ferris, D. R., Pezone, S., Tade, C., \& Tinti, S. (1997). Teacher commentary on student writing: Descriptions and implications. Journal of Second Language Writing, 6, 155-182.

Flowerdew, J. (2001). Attitudes of journal editors to nonnative speaker contributions, TESOL Quarterly, 35 (1), $121-150$.

Frazer, B. (1999). What are discourse markers? Journal of Pragmatics, 31: 931-953.

Gborsong, P. A., Awiah, J. W., \& Appartaim, A. B. (2018). Linguistic forms in teacher feedback comments on students' essays in colleges of education in Ghana. Journal of English Literature and Cultural Studies, 1(1), 59-94.

Glaser, B. G., \& Strauss, A. L. (1967). The discovery of grounded theory: Strategies for qualitative research, Chicago, Aldine Publishing Company

Halliday, M. A. K. (1978). Language as social semiotic: The social interpretation of language and meaning. Maryland: University Park Press.

Hao, J., \& Humphrey, S. (2012). The role of coupling in biological experimental reports. Linguistics and the Human Sciences, 5 (2), 169-194.

Henderson, J. A. (1982). Some psychological aspects of simultaneous interpreting. The Incorporated Linguist, 21(4), 149-152.

Horowitz, D. (1986a). Essay examination prompts and the teaching of academic writing. English for Specific Purposes, 5, 107-120.

Horowitz, D. (1986b). What professors actually require: Academic tasks for the ESL classroom. TESOL Quarterly, 20: 445-462.

Horowitz, D. (1989). Function and form in essay examination prompts. RELC Journal, 20, 23-35.

Hunston, S. (1993). Evaluation and ideology in scientific writing. In M. Ghadessy (Ed.), Register analysis: Theory and practice (pp. 57-73). London: Pinter.

Hunston, S., \& Thompson, G. (2000). Evaluation in text: Authorial stance and the construction of discourse: UK: Oxford University Press.

Hunston, S. (1994). Evaluation and organization in a sample of written academic discourse. In M. Coulthard (Ed.), Advances in written text analysis (pp. 191-218). London: Routledge.

Hunston, S. (2011). Corpus approaches to evaluation: Phraseology and evaluative language. New York: Routledge.

Huttner, J. (2010). The potential purpose-bult corpora in the analysis of student academic writing. Journal of Writing Research, 2(2), 197-218.

Hyland, K. (2000). Disciplinary discourses: Social interactions in academic writing. New York, NY: Longman.

Hyland, K. (2003). Dissertation acknowledgments: the anatomy of a Cinderella genre. Written Communication, $20(3), 242-268$.

Hyland, K. (2004a) Disciplinary interactions: Metadiscourse in L2 postgraduate writing. Journal of Second 
Language Writing, 13, 133-151.

Hyland, K. (2004b). Graduates' gratitude: the generic structure of dissertation acknowledgments. English for Specific Purposes, 23(3), 303-324.

Hyland, K. (2005). Stance and engagement: A model of interaction in academic discourse. Discourse Studies, $7(2), 173-192$.

Hyland, K. (2008). Disciplinary voices: Interactions in academic writing. English Text Construction, 1 (1), 5-22.

Hyland, K. (2009). Academic discourse: English in a global context. London, UK: Continuum.

Hyland, K. (2010). Constructing proximity: Relating to reads in popular and professional Science. English for Academic Purposes, 9, 116-127.

Hyland, K., \& Diani, G. (Eds.) (2009) Academic evaluation: Review genres in university settings. Basingstoke, U.K.: Palgrave Macmillan Ltd.

Hyland, K., \& Tse, P. (2004). Metadiscourse in academic writing: A reappraisal. Applied Linguistics, 25(2), 156177.

Ivanic, \& Camps (2001). Ivanic, R., \& Camps, D. (2001). I am how I sound voice as self-representation in L2 writing. Journal of Second Language Writing, 10, 3-33.

Jiang, F. K., \& Hyland, K. (2015). 'The fact that': Stance nouns in disciplinary writing. Discourse Studies, 17(5), 529-550.

Johns, A. (1997). Text, role, and context: Developing academic literacies. Cambridge: Cambridge University Press.

Kachru, B. (Ed.) (1992). The other tongue: English across cultures. Urbana, IL: University of Illinois Press.

Kumar, V., \& Stracke, E. (2011). Examiners' reports on theses: Feedback or assessment. Journal of English for Academic Purposes, 10, 211-222.

Lewis, M., \& Starks, D. (1997). Revisiting examination questions in tertiary academic writing. English for Specific Purposes, 10: 107-120.

Lillis, T., \& Curry, M. J. (2006). Professional academic writing by multilingual scholars: Interactions with literacy brokers in the production of English-medium texts. Written Communication, 23(1), 3-35.

Lim, M. H. (2008). Indicating significance of current research: Pedagogical implications of a genre analysis for dissertation writing. The Open Applied Linguistics Journal, 1, 46-55.

Lincoln, Y. S., \& Guba, E. G. (1985). Naturalistic inquiry. Newbury Park, CA: Sage.

Luo, N., \& Hyland, K. (2016). Chinese academics writing for publication: English teachers as text mediators. Journal of Second Language Writing, 32(3), 43-55.

Martin, J. R. (1992). English text: System and structure. Amsterdam: Benjamins.

Martin, J. R. (2000). Beyond exchange: Appraisal systems in English. In S. Hunston \& G. Thompson (Eds.), Evaluation in text: Authorial stance and the construction of discourse (pp. 142-175). Oxford: Oxford University Press

Martin, J. R., \& Rose, D. (2003). Working with discourse: Meaning beyond the clause. London and New York: Continuum.

Martin, J. R., \& White, P. R. (2005). The language of evaluation: Appraisal in English.

Matthiessen, C. M. I. M. (1995). Lexico-grammatical cartography: English Systems. Tokyo: International 
Afful, J. B. A., \& Twumasi, R. A.

Language Sciences. Basingstoke: Palgrave Macmillan.

Martinez, A. (2004). Discourse markers in the expository writing of Spanish university students. Iberica, 8, 6380.

Matsuda, P. (2001). Voice in Japanese written discourse: Implication for second language writing. Journal of Second Language Writing, 10, 35-53

Matthiessen, C. M. I. M. (1995). Theme as an enabling resource in ideational "knowledge" construction. In M. Ghadessy (Ed.), Thematic developments in English texts (pp. 20-55). London \& New York: Pinter.

Mauranen, A. (1993). Cultural differences in academic rhetoric: A text linguistic study. Frankfurt am Main: Peter Lang.

Musa, A. (2014). Hedging in academic writing: A pragmatic analysis of English and Chemistry Masters' theses in a Ghanaian university. English for Specific Purposes World, 42(15), 1-25.

Myers, G. (1985). Texts as knowledge claims: The social construction of two biology articles. Social Studies of Science, 15, 593-630.

Nartey, M., \& Mwinlaaru, I. N. (2019). Towards a decade of synergizing corpus linguistics and critical discourse analysis: A meta-analysis. Corpora, 14(2), 203-235.

Ngula, R. S. (2017). Epistemic modal verbs in research articles written by Ghanaian and international scholars: A corpus-based study of three disciplines. Brno Studies in English, 43(2), 5-27.

Olivier, A. \& Carstens, A. (2018). A heuristic framework for voice instruction at the doctoral level. Stellenbosch Papers in Linguistics Plus, 55, 7-26. https://doi.org/10.5842/55-0-768

Paré, A., Starke-Meyerring, D., \& McAlpine, L. (2009). The dissertation as multi-genre: Many readers, many readings. In C. Bazerman, A. Bonini, \& D. Figueiredo (Eds.). Genre in a changing world. Fort Collins, Colorado: The WAC Clearinghouse and Parlor Press.

Pascual, M. \& Unger, L. (2010). Appraisal in the research genres: An analysis of grant proposals by Argentinean researchers. Revista Signos, 43(73), 261-280.

Petticrew, M., \& Roberts, H. (2006). Systematic reviews in the social sciences: A practical guide. London; Blackwell.

Rice, P. L., \& Ezzy, D. (1999). Qualitative research methods: A health focus. Melbourne: Oxford University Press.

Santos, M.B. (1996). The textual organisation of research paper abstracts in applied linguistics, Text, 16 (4), $481 \square 99$.

Sarfu-Adu, K. (2015). Nominalizations in research article abstracts: A comparative study. European Journal Language Studies, 2(1),

Swales, J. (1990). Genre analysis: English in academic and research settings. Cambridge: Cambridge University Press.

Swales, J. (1996). Occluded genres in the academy: The case of the submission letter. In E. Ventola \& A. Mauranen (Eds.), Academic writing: Intercultural and textual issues. Amsterdam: John Benjamins.

Swales, J. (2004). Research genres: Explorations and applications. New York, NY: Cambridge University Press.

Tardy, C. M. (2005). 'It's like a story': Rhetorical knowledge development in advanced academic literacy. Journal of English for Academic Purposes, 4(4), 325-338.

122 Consortia Academia Publishing (A partner of Network of Professional Researchers and Educators) 
The language of evaluation in academic writing research in Ghana, 2000-2020: A synthesis

Tardy, C. M. (2009). Building genre knowledge. West Lafayette, IN: Parlor Press.

Thompson, G. (2014). Introducing functional grammar ( $\left.3^{\text {rd }} \mathrm{ed}\right)$. London: Routledge.

Thompson, G., \& Alba-Juez, L. (2014). Evaluation in context. (Eds.). Amsterdam/Philadelphia: John Benjamins.

Thompson, G., \& Hunston, S. (2000). Evaluation: An introduction. In S. Hunston \& G. Thompson (Eds.),

Evaluation in text: Authorial stance and the construction of discourse (pp. 1-27). Oxford: Oxford University Press.

Twumasi, R. A. (2012). Citation practices of graduate students in a Ghanaian university. Unpublished MPhil thesis. University of Cape Coast, Ghana.

Twumasi, R. A. (2020). Evaluative language in examiners' reports on MPhil theses in a Ghanaian university. Unpublished $\mathrm{PhD}$ thesis, University of Cape Coast, Ghana.

Vande Kopple, W. J. (1985). Metadiscourse and the recall of modality markers. Visible Language, 22, 233-27.

Vossler, J. J. (2007). Must it be perfect? An analysis of statements of purpose. Unpublished Thesis. School of Information and Library Science: University of North Carolina.

Yardley, L., \& Marks, D. F. (2004). Research methods for clinical and health psychology. London: Sage.

Yeboah, (2014). Discourse markers in literature review sections of dissertation. Unpublished BA dissertations, University of Cape Coast, Ghana.

Wang, D., \& An, X. (2013). A study of appraisal in Chinese academic book reviews. Journal of Language Teaching and Research, 4(6), 1247-1252. 
Afful, J. B. A., \& Twumasi, R. A. 